\title{
Pengaruh Perputaran Kas, Perputaran Persediaan, dan Perputaran Piutang Terhadap Return On Assets (ROA) pada PT. Indofood Sukses Makmur Tbk Periode 2008-2015
}

\author{
Dona Elvia Desi \\ Dosen Tetap STIE Sakti Alam Kerinci \\ dona.elde79@gmail.com
}

\begin{abstract}
This research aims to know the influence between the cash turnover, inventory turnover, and turnover accounts receivable against the Return on Asset (ROA) either partially or simultaneously on a PT Indofood 2008-2015 Makmur Tbk period of Success and to knowing the magnitude of influence between the cash turnover, inventory turnover, and turnover accounts receivable against the Return on Asset (ROA) either partially or simultaneously on a PT Indofood 2008-2015 Makmur Tbk Successful period. With linear regression equation enggumakan, double and test hypotheses as well as the determinant of the coefficient of $t$ and $F$ test then obtained simultaneous results that there is significant influence between the cash turnover, inventory turnover and accounts receivable turnover against the Return On Assets (ROA) on PT Indofood 2008-2015 Makmur Tbk Success period, this is evidenced by the value count $>F$ table $F$ and significant $>0.05$. Partially, there is no significant influence between the cash turnover against the Return On Assets (ROA) on PT Indofood 2008-2015 Makmur Tbk Success period, there were no significant effects between inventory turnover against the Return On Assets ( ROA) on PT Indofood 2008-2015 Makmur Tbk Successful period and there were no significant effects between turnaround receivable against the Return On Assets (ROA) on PT Indofood Successful Prosperous Tbk period 2008-this 2015 hal evidenced by each value t calculate < t table and significance $>0.05$.

Keywords: turnover turnover cash, inventory, accounts receivable turnover, ROA
\end{abstract}

\section{PENDAHULUAN}

Modal kerja merupakan masalah pokok dan topik penting yang sering kali dihadapi perusahaan, karena hampir semua perhatian manejer keuangan ditujukan untuk mengelola modal kerja dan aktiva lancar merupakan modal kerja yang cukup besar dari aktiva. Modal kerja dibutuhkan oleh setiap perusahaan untuk membelanjai setiap operasinya setiap hari, misalnya; untuk pembelian bahan mentah, membiayai upah pegawai dan lain-lain, dimana uang dan dana tersebut diharapkan dapat kembali lagi dalam perusahaan dalam waktu yang singkat melalui hasil penjualan produksinya. Begitu pula kemajuan perusahaan akan membiayai usahaanya, dimana makin besar perusahaan akan besar pula modal yang dibutuhkan oleh perusahaan itu sendiri tanpa adanya bantuan dari luar. Modal yang digunakan untuk investasi pada aktiva lancar disebut modal kerja. Komponen modal kerja antara lain kas, surat berharga, piutang, persediaan, hutang lancar. Modal kerja sama pentingnya seperti halnya masalah investasi jangka panjang, kebijakan deviden maupun merger dan reorganisasi.

Kas merupakan aktiva yang paling likuid yang dimiliki perusahaan, kas akan diurut atau ditempatkan sebagai komponen pertama dari aktiva lancar dalam 
neraca. Kas meliputi uang logam uang kertas, cek wesel pos dan deposito. Piutang juga merupakan bagian dari aktiva lancar yang merupakan bukti dari adanya penjualan kredit. Dalam praktek, piutang pada umumnya diklasifikasikan menjadi piutang usaha, piutang wesel, dan piutang lain-lain. Piutang usaha adalah jumlah yang akan ditagih dari pelanggan sebagai akibat penjualan barang atau jasa secara kredit. Piutang usaha biasanya diperkirakan akan dapat ditagih dalam jangka waktu yang relatif pendek, biasanya dalam waktu 30 hingga 60 hari. Piutang wesel adalah tagihan perusahaan kepada pembuat wesel. Pembuat wesel di sini adalah pihak yang telah berhutang kepada perusahaan, baik melalui pembelian barang atau jasa secara kredit maupun melalui pinjaman sejumlah uang. Perputaran persediaan merupakan komponen utama dari barang yang dijual, oleh karena itu semakin tinggi persediaan berputar semakin efektif perusahaan dalam mengelola perusahaan.Salah satu tujuan perusahaan adalah meningkatkan laba yang maksimal dalam menjalankan perusahaan dengan lebih efektif dan efisien serta dapat mengambil keputusan yang dapat menunjang terhadap pencapaian tujuan perusahaan tersebut dan meningkatkan kinerja perusahaan. Untuk mengetahui kinerja perusahaan dalam pencapaian laba, maka profitabilitas perusahaan harus diukur. Alat ukur yang digunakan dalam penelitian ini adalah return on asset (ROA).

Adapun faktor-faktor yang mempengaruhi Return On Assets (ROA) menurut Brigham dan Houston (2001:89) meliputi rasio likuiditas, rasio manajemen aktiva, dan rasio manajemen utang. Berdasarkan pernyataan diatas, faktor utama yang mempengaruhi Return On Assets (ROA) adalah rasio-rasio yang ada pada aktiva dan dapat mengukur nilai aktiva perusahaan, faktor tersebut adalah faktor yang mempengaruhi profitabilitas, maka dari itu ROA juga dipengaruhi oleh faktor-faktor tersebut.

Salah satu perusahaan yang mampu bersaing di era ketatnya persaingan bisnis sekarang ini adalah PT. Indofood Sukses Makmur,Tbk berdiri pada tahun 1990. Untuk melihat gambaran kondisi keuangan PT. Indofood Sukses Makmur berikut disajikan laporan keuangan perusahaan yang terdiri dari laporan neraca dan laporan laba/rugi PT. Indofood Sukses Makmur, Tbk periode 2008-2015.

Tabel 1

Laporan Neraca PT. Indofood Sukses Makmur Tbk Periode 2008-2015 (juta rupiah)

\begin{tabular}{|l|r|r|r|r|}
\hline \multirow{2}{*}{ Tahun } & \multicolumn{4}{|c|}{ Uraian } \\
\cline { 2 - 5 } & Kas (Rp) & Piutang (Rp) & $\begin{array}{c}\text { Persediaan } \\
\text { (Rp) }\end{array}$ & Total aktiva (Rp) \\
\hline 2008 & 4.271 .208 & 2.087 .348 & 6.061 .219 & 39.594 .264 \\
\hline Pertumbuhan & - & - & - & - \\
\hline 2009 & 4.474 .830 & 1.843 .516 & 5.117 .484 & 40.382 .953 \\
\hline Pertumbuhan & $\mathbf{4 , 7 6 \%}$ & $\mathbf{- 1 1 , 6 \%}$ & $\mathbf{- 1 5 , 5 \%}$ & $\mathbf{1 , 9 9 \%}$ \\
\hline 2010 & 10.439 .353 & 2.245 .977 & 5.644 .141 & 47.275 .955 \\
\hline Pertumbuhan & $\mathbf{1 3 3 , 2 \%}$ & $\mathbf{2 1 , 8 \%}$ & $\mathbf{1 0 , 2 \%}$ & $\mathbf{1 7 , 0 6 \%}$ \\
\hline
\end{tabular}




\begin{tabular}{|l|r|r|r|r|}
\hline 2011 & 13.049 .048 & 2.584 .084 & 6.536 .343 & 53.585 .933 \\
\hline Pertumbuhan & $\mathbf{2 4 , 9 \%}$ & $\mathbf{1 5 , 0 5 \%}$ & $\mathbf{1 5 , 8 \%}$ & $\mathbf{1 3 , 3 4 \%}$ \\
\hline 2012 & 13.343 .028 & 2.691 .271 & 7.782 .594 & 59.324 .207 \\
\hline Pertumbuhan & $\mathbf{2 , 2 5 \%}$ & $\mathbf{4 , 1 4 \%}$ & $\mathbf{1 9 , 0 6 \%}$ & $\mathbf{1 0 , 7 0 \%}$ \\
\hline 2013 & 13.666 .194 & 4.053 .300 & 8.160 .539 & 78.092 .789 \\
\hline Pertumbuhan & $\mathbf{2 , 4 2 \%}$ & $\mathbf{5 0 , 6 \%}$ & $\mathbf{4 , 8 5 \%}$ & $\mathbf{3 1 , 6 3 \%}$ \\
\hline 2014 & 14.157 .619 & 2.986 .729 & 8.454 .845 & 85.938 .885 \\
\hline Pertumbuhan & $\mathbf{3 , 6 0 \%}$ & $\mathbf{- 2 6 , 3 \%}$ & $\mathbf{3 , 6 0 \%}$ & $\mathbf{1 0 , 0 4 \%}$ \\
\hline 2015 & 13.076 .076 & 3.522 .553 & 7.627 .360 & 91.831 .526 \\
\hline Pertumbuhan & $\mathbf{- 7 , 6 3 \%}$ & $\mathbf{1 7 , 9 \%}$ & $\mathbf{- 9 , 7 8 \%}$ & $\mathbf{6 8 , 5 6 \%}$ \\
\hline
\end{tabular}

Sumber : PT. Indofood Sukses Makmur Tbk

Berdasarkan Tabel 1 diatas terlihat bahwa kas yang dimiliki perusahaan PT. Indofood Sukses Makmur Tbk periode 2008-2015 mengalami penurunan di akhir masa periode penelitian. Tahun 2008 jumlah kas Rp. 4.271.2008 pada tahun 2009 naik menjadi Rp. 4.474.830 atau sebesar $4,76 \%$ tahun 2010 jumlah kas mengalami kenaikan sebesar $\mathrm{Rp}$. 10.439.353 atau sebesar $133,2 \%$ Tahun 2011 jumlah kas naik menjadi Rp. 13.049.048 atau sebesar 24,9\%, tahun 2012 jumlah kas naik menjadi Rp. 13.343.028 atau naik sebesar 2,25\%, pada tahun 2013 jumlah kas naik menjadi Rp. 13.666.194 atau naik sebesar 2,42\%, pada tahun 2014 jumlah kas naik menjadi Rp. 14.157.619 atau sebesar 3,60\%, dan pada tahun 2015 jumlah kas menurun menjadi Rp. 13.076.076 atau mengalami penurunan sebesar $7,63 \%$.

Untuk piutang yang dimiliki perusahaan PT. Indofood Sukses Makmur Tbk periode 2008-2015 terlihat terus mengalami fluktuasi. Tahun 2008 jumlah piutang sebesar Rp. 2.087.348, tahun 2009 jumlah piutang turun menjadi Rp. 1.843.516 atau sebesar 11,6\%, tahun 2010 jumlah piutang naik menjadi Rp. 2.245.977 atau sebesar $21,8 \%$, Tahun 2011 piutang naik menjadi Rp. 2.584 .084 atau sebesar $15,05 \%$, pada tahun 2012 piutang menjadi Rp. 2.691.271 atau naik sebesar 4,14\%, pada tahun 2013 piutang mengalami kenaikan sebesar Rp 4.053.300 atau sebesar 50,6\%. pada tahun 2014 piutang mengalami penurunan menjadi Rp. 2.986.729 atau mengalami penurunan sebesar 26,3\%, dan pada tahun 2015 piutang kembali mengalami kenaikan menjadi Rp. 3.522.553 atau naik sebesar $17,94 \%$.

Sedangkan persediaan PT. Indofood Sukses Makmur Tbk periode 2008-2015 mengalami fluktuasi, dimana pada tahun 2008 jumlah persediaan Rp. 6.061.219, tahun 2009 jumlah persediaan turun menjadi Rp. 5.117.484 atau sebesar $15,5 \%$ tahun 2010 jumlah persediaan naik sebesar Rp. 5.644.141 atau sebesar $10,2 \%$ pada tahun 2011 jumlah persediaan naik menjadi Rp. 6.536 .343 atau sebesar $15,8 \%$ pada tahun 2012 persediaan mengalami kenaikan menjadi Rp. 7.782.594 atau naik sebesar $19,06 \%$, pada tahun 2013 persediaan mengalami kenaikan menjadi Rp. 8.160.539 atau naik sebesar 4,85\%, pada tahun 2014 persediaan mengalami kenaikan menjadi Rp. 8.454.845 atau sebesar $3,60 \%$, pada tahun 2015 persediaan mengalami penurunan menjadi $\mathrm{Rp}$. 7.627.360 atau mengalami penurunan sebesar $9,78 \%$. 
Jumlah total aktiva yang terlihat dari tabel di atas menunjukkan bahwa total aktiva PT. Indofood Sukses Makmur Tbk periode 2008-2015 terus mengalami kenaikan setiap tahunya. Tahun 2008 jumlah total aktiva Rp. 39.594.264 tahun 2009 total aktiva naik menjadi Rp. 40.382 .953 atau sebesar 1,99\% tahun 2010 total aktiva mengalami kenaikan sebesar Rp. 47.275.955 atau sebesar 17,06\% Tahun 2011 jumlah total aktiva kembali mengalami kenaikan Rp. 53.585.933 atau sebesar 13,34\%, tahun 2012 menjadi Rp. 59.324.207 atau sebesar 10,70\%, tahun 2013 menjadi Rp. 78.092.789 atau sebesar 31,63\%, pada tahun 2014 total aktiva naik menjadi Rp. 85.938.885 atau naik sebesar 10,04\% dan pada tahun 2015 total aktiva naik menjadi Rp. 91.831.526 atau naik sebesar $68,56 \%$.

\section{Tabel 2}

Laporan Laba Rugi PT. Indofood Sukses Makmur Tbk Periode 2008-2015 (juta rupiah)

\begin{tabular}{|l|r|r|r|}
\hline \multirow{2}{*}{ Tahun } & \multicolumn{3}{|c|}{ Uraian } \\
\cline { 2 - 4 } & $\begin{array}{c}\text { Penjualan bersih } \\
\text { (Rp) }\end{array}$ & $\begin{array}{c}\text { Harga pokok } \\
\text { penjualan (Rp) }\end{array}$ & $\begin{array}{c}\text { Laba/Rugi bersih } \\
\text { (Rp) }\end{array}$ \\
\hline $\mathbf{2 0 0 8}$ & 38.799 .279 & 29.822 .362 & 1.034 .389 \\
\hline Pertumbuhan & - & - & - \\
\hline $\mathbf{2 0 0 9}$ & 37.140 .830 & 27.018 .884 & 2.075 .861 \\
\hline Pertumbuhan & $\mathbf{- 4 , 2 7 \%}$ & $\mathbf{9 , 4 0 \%}$ & $\mathbf{1 0 0 , 6 \%}$ \\
\hline $\mathbf{2 0 1 0}$ & 38.403 .360 & 25.932 .908 & 2.952 .858 \\
\hline Pertumbuhan & $\mathbf{3 , 3 9 \%}$ & $\mathbf{4 , 0 1 \%}$ & $\mathbf{4 2 , 2 \%}$ \\
\hline $\mathbf{2 0 1 1}$ & 45.332 .256 & 32.749 .190 & 5.017 .425 \\
\hline Pertumbuhan & $\mathbf{1 8 , 0 4 \%}$ & $\mathbf{2 6 , 2 8 \%}$ & $\mathbf{6 9 , 9 \%}$ \\
\hline $\mathbf{2 0 1 2}$ & 50.059 .427 & 36.493 .332 & 4.871 .745 \\
\hline Pertumbuhan & $\mathbf{1 0 , 4 2 \%}$ & $\mathbf{1 1 , 4 3 \%}$ & $\mathbf{- 2 , 9 0 \%}$ \\
\hline $\mathbf{2 0 1 3}$ & 57.731 .998 & 43.402 .144 & 5.161 .247 \\
\hline Pertumbuhan & $\mathbf{1 5 , 3 2 \%}$ & $\mathbf{1 8 , 9 3 \%}$ & $\mathbf{5 , 9 4 \%}$ \\
\hline $\mathbf{2 0 1 4}$ & 63.594 .452 & 46.544 .646 & 4.812 .618 \\
\hline Pertumbuhan & $\mathbf{1 0 , 1 5 \%}$ & $\mathbf{7 , 2 4 \%}$ & $\mathbf{- 6 , 7 5 \%}$ \\
\hline $\mathbf{2 0 1 5}$ & 64.061 .947 & 46.803 .889 & 4.867 .347 \\
\hline Pertumbuhan & $\mathbf{0 , 7 \%}$ & $\mathbf{0 , 5 \%}$ & $\mathbf{1 , 1 3 \%}$ \\
\hline Syyy
\end{tabular}

Sumber : PT. Indofood Sukses Makmur Tbk

Berdasarkan Tabel 2 diatas terliahat bahwa penjualan bersih perusahaan PT. Indofood Sukses Makmur Tbk periode 2008-2015 mengalami fluktuasi. Pada tahun 2008 jumlah penjualan bersih Rp. 38.799.279 tahun 2009 penjualan bersih Rp. 37.140.830 atau sebesar $4,27 \%$ tahun 2010 jumlah penjualan bersih naik Rp. 38.403.360 atau sebesar 3,39\% Tahun 2011 jumlah penjualan bersih mengalami kenaiakn Rp. 45.332.256 atau sebesar 18,04\%, tahun 2012 naik menjadi Rp. 50.059.427 atau sebesar 10,42\%, pada tahun 2013 jumlah penjualan bersih naik menjadi $\mathrm{Rp}$. 57.731 .998 atau naik sebesar $15,32 \%$ , tahun 2014 jumlah penjualan bersih naik menjadi Rp. 63.594.452 atau sebesar $10,15 \%$ dan pada tahun 2015 jumlah penjualan bersih naik menjadi Rp. 64.061.947 atau naik sebesar 0,7\%. Harga pokok 
penjualan yang dimiliki perusahaan PT. Indofood Sukses Makmur Tbk periode 2008-2015 mengalami fluktuasi. Pada tahun 2008 harga pokok penjualan berjumlah Rp. 29.822.362 tahun 2009 harga pokok penjualan mengalami penurunan Rp. 27.018 .884 atau sebesar $9,40 \%$ tahun 2010 harga penjualan pokok kembali mengalami penurunan sebanyak $\mathrm{Rp}$. 25.932.908 atau sebesar 4,01\% Tahun 2011 harga pokok penjualan mengalami kenaikan sebesar Rp. 32.749 .190 atau $26,28 \%$ tahun 2012 harga pokok penjua;lan naik menjadi Rp.36.493.332 atau naik sebesar $11,43 \%$, tahun 2013 harga pokok penjualan naik menjadi Rp. 43.402.144 atau naik sebesar $18,93 \%$, tahun 2014 harga pokok penjualan naik menjadi Rp. 46.544.646 atau sebesar 7,24\% dan pada tahun 2015 harga pokok penjualan naik menjadi Rp. 46.803.889 atau naik sebesar 0,5\%.

Sedangkan laba bersih yang terlihat dari tabel diatas menunjukkan bahwa laba bersih PT. Indofood Sukses Makmur Tbk periode 2008-2015 mengalami fluktuasi. Pada tahun 2008 jumlah laba bersih Rp. 1.034.389, tahun 2009 jumlah laba bersih mengalami kenaikan Rp. 2.075.861 atau sebesar $100,6 \%$ tahun 2010 laba bersih mengalami kenaikan sebesar Rp. 2.952 .858 atau sebesar $42,2 \%$, Tahun 2011 jumlah laba bersih mengalami kenaikan Rp.5.017.425 atau sebesar 69,9\%, tahun 2012 mengalami penurunan menjadi Rp. 4.871 .745 atau mengalami penurunan sebesar 2,90\%, tahun 2013 jumlah laba bersih mengalami kenaikan menjadi Rp. 5.161.247 atau naik sebesar $5,94 \%$, pada tahun 2014 jumlah Laba bersih mengalami penurunan menjadi Rp. 4.812.618 atau sebesar $6,75 \%$ dan pada tahun 2015 jumlah laba bersih naik menjadi Rp. 4.867.347 atau naik sebesar $1,13 \%$. Tujuan penelitian ini adalah untuk mengetahui pengaruh antara perputaran kas, perputaran persediaan, dan perputaran piutang terhadap Return on Asset (ROA) baik secara parsial maupun simultan pada PT. Indofood Sukses Makmur Tbk periode 2008-2015, dan untuk mengetahui besarnya pengaruh antara perputaran kas, perputaran persediaan, dan perputaran piutang terhadap Return on Asset (ROA) baik secara parsial maupun simultan pada PT. Indofood Sukses Makmur Tbk periode 2008-2015.

\section{Tinjauan Pustaka \\ Return On Assets (ROA)}

Menurut Harahap (2010:305)

Return On Assets (ROA) menggambarkan perputaran aktiva diukur dari penjualan. Semakin besar rasio ini maka semakin baik dan hal ini berarti aktiva dapat cepat meraih laba. Menurut Kasmir (2008:201) Return On Assets (ROA) merupakan rasio yang menunjukkan hasil (return) atas jumlah aktiva yang digunakan dalam perusahaan. Menurut Siamat (2004:102) Return On Assets (ROA) adalah rasio ini digunakan untuk mengukur manajemen perusahaan dalam memperoleh keuntungan (laba) secara keseluruhan. Menurut Sudana (2011:22) Return On Assets (ROA) menunjukkan kemampuan perusahaan dengan menggunakan seluruh aktiva yang dimiliki untuk menghasilkan laba setelah pajak. Menurut Mardiyanto (2009:196) ROA adalah rasio yang digunakan untuk mengukur kemampuan perusahaan dalam menghasilkan laba dari aktivitas investasi. Berdasarkan pernyataan diatas dapat disimpulkan bahwa Return On Assets (ROA) 
merupakan rasio yang menunjukkan seberapa banyak laba bersih yang bisa diperoleh dari seluruh kekayaan yang dimiliki perusahaan. karena itu digunakan angka laba setelah pajak dan rata-rata kekayaan perusahaan, dengan demikian rasio ini menghubungkan keuntungan yang diperoleh dari operasinya perusahaan dengan jumlah investasi atau aktiva yang digunakan untuk menghasilkan keuntungan operasi tersebut. Menurut Kasmir (2008:21) rumus yang digunakan menghitung ROA adalah sebagai berikut :

ROA $=\frac{\text { Laba bersih }}{\text { Total aktiva }}$

Sedangkan menurut Brigham dan Houston (2010:148) rumus yang digunakan untuk menghitung ROA adalah sebagai berikut

ROA $=\frac{\text { Laba bersih }}{\text { Total aktiva }} \times 100 \%$

Laba bersih adalah kelebihan seluruh pendapatan atas seluruh biaya untuk suatu periode tertentu setelah dikurangi pajak penghasilan yang disajikan dalam bentuk laporan laba rugi. Sedangkan total aktiva adalah keseluruhan aktiva lancar yaitu uang kas dan aktiva-aktiva lain atau sumber-sumber lainya.

\section{Faktor-faktor yang mempengaruhi Return On Assets (ROA)}

Beberapa faktor yang mempengaruhi Return On Assets (ROA) menurut Brigham dan Houston (2001:89) yaitu :

1. Rasio likuiditas, merupakan rasio yang digunakan untuk mengukur kemampuan perusahaan dalam memenuhi kewajiban jangka pendeknya dengan membandingkan aktiva lancar perusahaan dengan kewajiban lancar.
2. Rasio manajemen aktiva, merupakan rasio yang mengukur seberapa efektif perusahaan mengelola aktivanya. seperti rasio perputaran kas, prputaran persediaan dan perputaran piutang.

3. Rasio manajemen utang, merupakan rasio yang digunakan untuk mengetahui sejauh mana kemampuan perusahaan memenuhi kewajiban jangka panjang (utang) perusahaan yang digunakan untuk membiayai seluruh aktivitas perusahaan.

Berdasarkan pernyataan diatas faktor utama yang mempengaruhi Return On Assets (ROA) adalah rasio-rasio yang ada pada aktiva dan dapat mengukur nilai aktiva perusahaan, faktor tersebut adalah faktor yang mempengaruhi profitabilitas maka dari itu ROA juga dipengaruhi faktor-faktor tersebut.

\section{Perputaran Kas}

Kas merupakan alat pertukaran dan alat pembayaran yang diterima untuk pelunasan hutang, dan dapat diterima sebagai setoran dengan jumlah sebesar nilai nominalnya. Kas adalah modal kerja yang sifatnya sangat likuid, semakin besar jumlah nominal kas yang terdapat pada suatu perusahaan artinya makin tinggi tingkat likuiditasnya. Yang termasuk dalam kas adalah seluruh alat pembayaran yang dapat digunakan dengan segera seperti uang logam, uang kertas, dan saldo giro rekening di bank. Kas dapat dikatakan merupakan satusatunya pos yang paling penting dalam neraca, karena berlaku sebagai alat tukar dalam perekonomian kita. Menurut Munawir (2010:14) kas adalah uang tunai yang dapat 
digunakan untuk membiayai operasi perusahaan. Menurut Riyanto (2011:94) kas adalah salah satu unsur modal kerja yang paling tinggi tingkat likuiditasnya. Sedangkan menurut Rahman (2013:132) kas adalah yang pembayaran yang siap dan bebas digunakan untuk membiayai kegiatan umum perusahaan. Menurut Riyanto (20011:455) semakin tinggi perputaran kas maka semakin baik, karena ini berarti semakin tinggi efisiensi penggunaan kasnya dan keuntungan yang diperoleh akan semakin besar. Menurut Munawir (2007:240) perputaran kas yaitu untuk menjadi kas kembali dalam jangka waktu satu tahun. Rasio ini dengan membagi antara penjualan dengan kas.

$\begin{array}{ll}\text { Menurut } & \text { Sutrisno (2007:48) } \\ \text { perputaran kas merupakan }\end{array}$ berputarnya kas menjadi kas kembali dalam jangka waktu satu tahun. Rasio ini untuk mengetahui kecepatan perputaran kas dalam periode tertentu dibandingkan dengan tahun berikutnya apakah terjadi peningkatan perputaran kas atau sebaliknya. Untuk itu dalam menjalankan usahanya setiap perusahaan membutuhkan uang tunai atau kas yang diperlukan untuk membiayai operasi perusahaan sehari-hari walaupun untuk mengadakan investasi baru dalam aktiva tetap. Jadi kas harus siap tersedia untuk digunakan membiayai operasi dan membayar kewajiban lancar perusahaan dan harus bebas dari setiap ikatan konseptual yang membatasi penggunaanya. Jumlah kas dapat pula dihubungkan dengan jumlah penjualan, perbandingan antar penjualan dengan jumlah ratarata kas menggambarkan tingkat perputaran kas (cas turnover). Perputaran kas merupakan kemampuan kas dalam menghasilkan pendapatan sehingga dapat dilihat berapa kali uang kas berputar dalam satu periode.

Menurut Hanafi dan Halim (2005:82), perputaran kas dapat dihitung menggunakan rumus sebagai berikut :

Perputaran kas $=\frac{\text { Penjualan bersih }}{\text { Rata }- \text { rata kas }}=\ldots .$.

kali

Menurut Sutrisno (2007:48) perputaran kas dapat dihitung dengan rumus sebagai berikut:

Perputaran kas $=\frac{\text { Penjualan }}{\text { Rata }- \text { rata kas }}=\ldots \ldots \ldots \ldots$.

kali

Menurut Martono (2004:72) rumus yang digunakan untuk perputaran kas adalah :

Perputaran kas $=\frac{\text { Penjualan }}{\text { Rata }- \text { rata kas }}=\ldots \ldots \ldots . .$.

kali

Penjualan bersih (Net Sales) adalah hasil penjualan bruto atau kotor sesudah dikurangi dengan berbagai potongan serta pengurangan lainya. Faktor-faktor yang mempengaruhi ketersediaan kas bisa melalui penerimaan dan pengeluaran kas. Menurut Riyanto (2001:289), perubahan yang efeknya menambah dan mengurangi kas dan dikatakan sebagai sumber-sumber penerimaan dan pengeluaran kas adalah sebagai berikut:

1. Berkurang dan bertambahnya aktiva lancar selain kas

Berkurangnya aktiva lancar selain kas berarti bertambahnya dana atau kas, hal ini dapat terjadi karena terjualnya barang tersebut, dan hasil penjualan tersebut merupakan sumber dana atau kas bagi perusahaan itu. Bertambahnya aktiva lancar dapat terjadi karena pembelian 
barang, dan pembelian barang membutuhkan dana.

2. Berkurang dan bertambahnya aktiva tetap

Berkurangnya aktiva tetap berarti bahwa sebagian dari aktiva tetap itu dijual dan hasil penjualannya merupakan sumber dana dan menambah kas perusahaan. Bertambahnya aktiva tetap dapat terjadi karena adanya pembelian aktiva tetap dengan menggunakan kas. Penggunaan kas tersebut mengurangi jumlah kas perusahaan

3. Bertambah dan berkurangnya setiap jenis hutang

Bertambahnya hutang, baik hutang lancar maupun hutang jangka panjang berarti adanya tambahan kas yang diterima oleh perusahaan. Berkurangnya hutang, baik hutang lancar maupun hutang jangka panjang dapat terjadi karena perusahaan telah melunasi atau mengangsur hutangnya dengan menggunakan kas sehingga mengurangi jumlah kas.

4. Bertambahnya modal

Bertambahnya modal dapat menambah kas misalnya disebabkan karena adanya emisi saham baru, dan hasil penjualan saham baru. Berkurangnya modal dengan menggunakan kas dapat terjadi karena pemilik perusahaan mengambil kembali atau mengurangi modal yang tertanam dalam perusahaan sehingga jumlah kas berkurang.

5. Adanya keuntungan dan

kerugian dari operasi perusahaan Apabila perusahaan mendapatkan keuntungan dari operasinya berarti terjadi penambahan kas bagi perusahaan yang bersangkutan sehingga penerimaan kas perusahaan pun bertambah. Timbulnya kerugian selama periode tertentu dapat menyebabkan ketersediaan kas berkurang karena perusahaan memerlukan kas untuk menutup kerugian. Dengan kata lain, pengeluaran kas bertambah sehingga ketersediaan kas menjadi berkurang.

\section{Perputaran Persediaan}

Persediaan adalah aset yang tersedia untuk dijual dalam kegiatan usaha normal, dalam proses produksi dan atau dalam perjalanan atau dalam bentuk bahan atau perlengkapan untuk digunakan dalam proses produksi atau pemberian jasa serta sangat menentukan kelancaran operasi perusahaan. Untuk mengetahui efektivitas pengelolaan persediaan dapat dilihat dari perhitungan tingkat perputaran persediaanya, karena semakin tinggi tingkat perputaran persediaan akan menunjukkan semakin pendek waktu terikatnya modal dalam persediaan sehingga untuk memenuhi volume penjualan tertentu dalam naiknya perputaran persediaan maka dibutuhkan jumlah modal kerja yang lebih kecil. Menurut Sartono (2010:443) persediaan adalah salah satu jenis aktiva lancar yang jumlahnya cukup besar dalam suatu perusahaan. Menurut Kasmir (2008:41) persediaan merupakan sejumlah barang yang disimpan oleh perusahaan dalam suatu tempat (gudang). Menurut Weygandt, Kieso dan Kimmel (2008:400), perputaran persediaan untuk mengkur berapa kali rata-rata persediaan dijual satu periode. Dapat dihitung dengan membagi harga pokok penjualan dengan persediaan rata-rata. 
Menurut Harahap (2008:308), Perputaran persediaan adalah menunjukkan seberapa cepat perputaran persediaan dalam siklus produksi normal. Semakin cepat perputaranya semakin baik karena dianggap kegiatan penjualan berjalan cepat. Menurut Munawir (2004:456) menyatakan bahwa semakin tinggi tingkat perputaran persediaan akan memperkecil resiko terhadap kerugian yang disebabkan karena penurunan harga atau karena perubahan selera konsumen, disamping itu akan menghemat ongkos penyimpanan dan pemeliharaan terhadap persediaan tersebut.

Menurut Brigham dan Houston (2010:136) perputaran persediaan merupakan rasio dimana penjualan dibagi dengan aset. Sesuai dengan namanya, rasio ini menunjukkan berapa kali pos tersebut berputar sepanjang tahun. Perputaran persediaan dapat dihitung dengan rumus:

Perputaran Persediaan = $\frac{\text { Harga pokok penjualan }}{\text { Rata-rata persediaan }}=\ldots .$. kali

Menurut Raharjaputra (2009:456) perputaran persediaan dapat dihitung dengan menggunakan rumus :

Perputaran Persediaan = $\frac{\text { Harga pokok penjualan }}{\text { Rata-rata persediaan }}=\ldots .$. kali

Harga pokok penjualan adalah semua biaya yang muncul dalam rangka menghasilkan suatu produk hingga produk tersebut siap dijual.

Jenis-jenis

persediaan menurut munawir (2007:16) meliputi : Persediaan bahan mentah, Persediaan barang dalam proses, dan Persediaan barang jadi
Menurut Hanafi (2010:218) biaya yang berkaitan dengan persediaan adalah:

1) Biaya investasi adalah biaya yang berupa biaya kesempatan karena dana tertanam di persediaan bukannya tertanam pada investasi lainya.

2) Biaya penyimpanan adalah biaya yang mencakup biaya ekplistit dan biaya inflist.

3) Biaya order adalah biaya yang mencakup biaya administrasi yang berkaitan dengan aktifitas memesan persediaan, biaya transportasi dan biaya pengangkutan persediaan.

Adapun manfaat menghitung perputaran persediaan (inventory turn over) bagi suatu perusahaan yaitu :

1) Dapat diketahui apakah pengelolaan persediaan telah dilakukan dengan baik atau tidak.

2) Dapat diketahui kecepatan dari pergantian persediaan dimana semakin tinggi pergantian persediaan, maka semakin tinggi biaya yang dapat dihemat sehingga laba perusahaan naik.

\section{Perputaran Piutang}

Perputaran piutang memberikan pandangan mengenai kualitas piutang perusahaan dan seberapa berhasilnya perusahaan dalam penagihanya. Semakin cepat perputaran piutang menandakan bahwa modal dapat digunakan secara efisien. Hal tersebut sejalan dengan pernyataan yang dikemukakan oleh Munawir (2002:75) yaitu, semakin tinggi (turn over) menunjukan modal kerja yang ditanamkan dalam piutang rendah, sebaliknya kalau rasio semakin rendah berarti ada over investment dalam piutang sehingga 
memerlukan analisa lebih lanjut, mungkin karena bagian kredit dan penagihan bekerja tidak efektif atau mungkin ada perubahan dalam kebijaksanaan pemberian kredit. Menurut Gitosudarmo (2002:81), piutang merupakan aktiva atau kekayaan perusahaan yang timbul sebagai akibat dari dilaksanakanya kebijakan penjualan kredit. Rasio perputaran piutang mengukur berapa kali rata-rata piutang dapat Tertagih selama satu periode. Pengelolaan piutang suatu perusahaan dapat dilihat dari tingkat perputaran piutangnya, dimana tingkat perputaran piutang modal kerja dalam kondisi berputar yaitu dari kas, proses komoditi, penjualan, piutang, dan kembali ke kas. Menurut Sumarso (2004:338), definisi piutang adalah kebiasaan bagi perusahaan untuk memberikan kelonggaran kepada para pelanggan pada waktu melakukan penjualan. Kelongaran-kelongaran yang diberikan biasanya dalam bentuk memperbolehkan para pelanggan tersebut membayar kemudian atas penjualan barang atau jasa yang dilakukan.

Menurut Kasmir (2011:176) perputaran piutang merupakan rasio yang digunakan untuk mengukur berapa lama penagihan piutang selama satu periode atau berapa kali dana yang ditanam dalam piutang ini berputar dalam satu periode. Jadi dari pernyataan-pernyataan di atas dapat disimpulkan bahwa piutang merupakan klaim perusahaan kepada pihak lain atas uang, barang-barang atau jasa-jasa dimana klaim tersebut muncul karena adanya penjualan barang atau jasa secara kredit. Piutang selalu dalam keadaan berputar, periode perputarannya atau periode terikatnya modal dalam piutang adalah tergantung kepada syarat pembayaranya. Rasio perputaran piutang memberikan analisa mengenai beberapa kali tiap tahunya dana yang tertanam dalam piutang berputar dari bentuk piutang uang tunai, kemudian kembali kebentuk piutang lagi.

Menurut Husnan (2004:22), perputaran piutang dapat dihitung dengan menggunakan rumus sebagai berikut :

Perputaran $\quad$ piutang
$\frac{\text { Penjualan }}{\text { Rata-rata piutang }}=\ldots .$. kali

Menurut Martono (2004:72) rumus yang digunakan untuk perputaran piutang adalah :

Perputaran piutang = $\frac{\text { Penjualan }}{\text { Rata-rata piutang }}=\ldots . . . \mathrm{kali}$

Menurut Riyanto (2002:83) menghitung perputaran piutang berdasarkan rumus sebagai berikut :

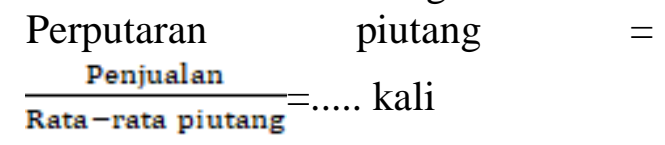
Adapun faktor-faktor yang mempengaruhi besar kecilnya piutang menurut Riyanto (2002:85), yaitu:

1. Volume penjualan kredit

Makin besar volume penjualan kredit yang dilakukan, makin besar pula investasi yang ditanamkan dalam piutang. Semakin besarnya volume penjualan kredit tiap tahunya berarti perusahaan itu harus menyediakan investasi lebih besar lagi dalam piutang. Makin besar jumlah piutang berarti semakin besar resikonya, tetapi bersamaan dengan itu juga memperbesar profitabilitasnya.

2. Syarat pembayaran penjualan kredit 
Syarat pembayaran penjualan kredit dapat bersifat ketat atau lunak. Apabila perusahaan menetapkan syarat pembayaran yang ketat berarti perusahaan lebih mengutamakan keselamatan kredit dari pada profitabilitasnya. Semakin panjang batas waktu pembayaran kredit berarti semakin besar jumlah piutangnya.

3. Ketentuan tentang pembatasan kredit

Pembatasan kredit juga harus ditetapkan oleh perusahaan dalam memberikan kredit. Makin tinggi pembatasan kredit yang ditetapkan bagi masingmasing langganan, berarti semakin besar pula dana yang diinvestasikan dalam piutang.

4. Kebijakan dalam mengumpulkan piutang

Kebijakan pengumpulan piutang oleh perusahaan dapat dilakukan secara aktif maupun pasif. Apabila perusahaan menerapkan kebijaksanaan pengumpulan piutang secara aktif, artinya perusahaan melakukan penagihan sendiri, maka perusahaan akan mengeluarkan biaya yang lebih besar.

5. Kebiasaan membayar dari para pelangga

Kebiasaan membayar ini menyangkut pemanfaatan discount period, semakin kecil investasi yang ditanamkan dalam piutang.

\section{Pengaruh perputaran kas, perputaran persediaan dan perputaran piutang terhadap Return On Assets (ROA)}

a. Pengaruh perputaran kas terhadap Return On Assets (ROA)
Berbagai teori mengenai kas mengemukakan bahwa kas merupakan elemen aktiva lancar yang paling liquid dan tingkat perputaranya merupakan indikator apakah perusahaan mengalami keuntungan atau sebaliknya. Semakin besar kas yang ada pada perusahaan, berarti semakin tinggi tingkat liquiditas perusahaan. Ini berarti bahwa perusahaan dapat memenuhi segala kewajiban yang ada dan dapat lebih cepat dalam menentukan kebijakan yang berhubungan dengan financial perusahaan karena kas merupakan elemen yang paling mudah diterima dalam transaksi operasional. Menurut Riyanto (2012:95) semakin tinggi perputaran kas ini akan semakin baik, berarti semakin tinggi efisiensi penggunaan kasnya dan keuntungan yang diperoleh akan semakin besar begitupun sebaliknya jika perputaran kas semakin rendah akan semakin buruk penggunaan kas dan keuntungan yang diperoleh perusahaan akan semakin kecil. Menurut Syamsudin (2002:236) semakin besar cash turnover, semakin sedikit jumlah kas yang dibutuhkan dalam operasi perusahaan, sehingga demikian cash turnover haruslah dimaksimalkan agar dapat memberikan keuntungan (ROA) bagi perusahaan.

b. Pengaruh perputaran persediaan terhadap Return On Assets (ROA)

Persediaan merupakan aktiva yang harus dikelola dengan baik, kesalahan dalam pengelolaan akan mengakibatkan komponen aktiva lain menjadi tidak optimal, bahkan bisa 


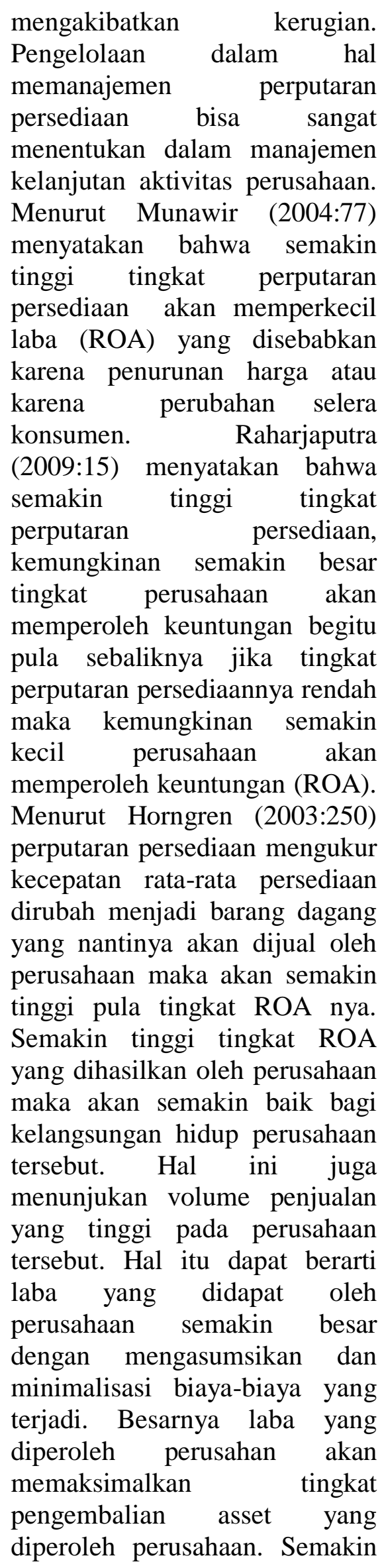

besar tingkat pengembalian asset (Return on asset) yang diperoleh perusahaan merupakan salah satu indikasi bahwa profitabilitas perusahaan menunjukan kondisi yang baik

c. Pengaruh perputaran piutang terhadap Return On Assets (ROA).

Piutang merupakan elemen aktiva lancar yang timbul karena adanya penjualan kredit. Timbulnya piutang diharapkan bisa menjadi solusi akan permasalahan yang timbul karena pihak manajemen kesulitan untuk memaksakan penjualan tunai, sehingga piutang menjadi alternatif agar perse, diaan bisa berputar hingga menjadi kas. Selain menjadi solusi, piutang juga bisa menjadi permasalahan apabila perputarannya tidak diawasi pembayaranya. Menurut (Riyanto 2010:90) perputaran piutang menunjukkan periode terikatnya modal kerja dalam piutang dimana semakin cepat periode berputarnya menunjukkan semakin cepat perusahaan mendapatkan keuntungan dari penjualan kredit tersebut, sehingga ROA perusahaan juga ikut meningkat. Apabila perusahaan menetapkan syarat pembayaran ketat berarti bahwa perusahaan lebih mengutamakan keselamatan kredit dari pada pertimbangan ROA. Menurut Supriyono (2009:11) penurunan perputaran piutang disebabkan karena lamanya penagihan piutang sehingga semakin lama pula piutang tersebut diubah menjadi kas, akibatnya perusahaan untuk meningkatkan laba berkurang 
dan akhirnya Return On Assets (ROA) dapat menurun.

\section{METODE}

Dalam penelitian ini penulis menggunakan metode penelitian berupa studi kepustakaan (library research) yakni dengan cara pengembalian data yang dilakukan dengan membaca buku-buku, literatur-literatur secara tulisan ilmiah yang berkaitan dengan masalah yang dibahas. Serta pengambilan data melalui internet pada Website PT. Indofood Sukses Makmur dan pada website resmi Bursa Efek Indonesia (www.idx.co.id). Jenis data yang digunakan dalam penelitian ini adalah data sekunder yaitu data summary of financial statment dari perusahaan yang siap untuk digunakan untuk penelitian atau merupakan hasil olahan pihak lain yang diperoleh dari website resmi PT. indofood sukses makmur dan dari website resmi Bursa Efek Indonesia (www.idx.co.id) dan literatur-literatur serta tulisan yang berkaitan dengan masalah yang dibahas.

Data yang diperoleh dalam penelitian berasal dari website Bursa Efek Indonesia (www.idx.co.id), website resmi PT. Indofood Sukses Makmur, literatur yang berkaitan dengan masalah penelitian.

\section{Analisis Regresi Linear Berganda}

Untuk mengetahui pengaruh dari perputaran kas, perputaran persediaan dan perputaran piutang terhadap return on assets (ROA) pada PT. Indofod Sukses Makmur, Tbk periode 2008-2015, digunakan rumus Sugiyono (2006:78) sebagai berikut :

$\mathrm{Y}=\alpha+\beta 1 \mathrm{X} 1+\beta 2 \mathrm{X} 2+\beta 3 \mathrm{X} 3+\mathrm{e}$
Keterangan : $\mathrm{Y}=$ Return On Assets $($ ROA $) ; \alpha=$ Konstanta; $\beta 1-\beta 3=$ Koefesien regresi; $X 1=$ Perputaran kas; $\mathrm{X} 2$ = Perputaran persediaan; X3 $=$ Perputaran piutang; dan $\mathrm{e}=$ error

\section{Koefesien Determinasi}

Untuk mengetahui besar kecilnya sumbangan $\mathrm{X}$ terhadap $\mathrm{Y}$ dapat ditentukan dengan rumus dari Sugiyono (2006 : 67) sebagai berikut :

$\mathrm{KD}=\mathrm{R}^{2} \times 100 \%$

Keterangan : $\mathrm{KD}=$ Koefesien determinasi; $\mathrm{R}=$ Koefesien korelasi

\section{Hipotesis}

Hipotesis adalah dugaan atau jawaban sementara terhadap masalah yang akan diuji kebenaranya melalui analisis data yang relevan dan kebenaranya akan diketahui setelah dilakukan penelitian. Berdasarkan hasil penelitian terdahulu dapat ditetapkan hipotesis sebagai berikut :

\begin{tabular}{|c|c|}
\hline & \\
\hline Ho $: r=0$ & $\begin{array}{lr}\text { tidak } & \text { terdapat } \\
\text { pengaruh } & \text { yang }\end{array}$ \\
\hline & signifikan \\
\hline & $\begin{array}{l}\text { simultan dan parsial } \\
\text { antara perputaran }\end{array}$ \\
\hline & kas, perputaran \\
\hline & persediaan dan \\
\hline & perputaran piutang \\
\hline & terhadap Return On \\
\hline & Assets (ROA). \\
\hline Ia $: r \neq 0$ & terdapat pengaruh \\
\hline & yang signifikan \\
\hline & secara simultan dan \\
\hline & parsial \\
\hline & perputaran \\
\hline & perputaran \\
\hline & persediaan \\
\hline & perputaran piutang \\
\hline & $\begin{array}{l}\text { terhadap Return On } \\
\text { Assets (ROA). }\end{array}$ \\
\hline
\end{tabular}

Uji Hipotesis 
Analisis statistik dilakukan dengan tahapan, pertama pengujian asumsi klasik, penaksiran persamaan regresi dan terakhir dengan melakukan pengujian hipotesis yang secara terinci dijelaskan sebagai berikut :

\section{Uji Statistik t (Parsial)}

Untuk menguji hipotesis secara parsial dilakukan dengan uji $\mathrm{t}$ dengan rumus yang dikemukakan oleh Sugiyono (2006 : 145 ).

$$
r \sqrt{n-2}
$$

t hitung $=$

$$
\sqrt{1+2}
$$

Keterangan $: \mathrm{t}=$ Nilai signifikan; $\mathrm{r}^{2}=$ Koefesien korelasi; $\mathrm{N}=$ Jumlah

\section{sampel}

Kriteria pengujian signifikansi :

1. Jika $\mathrm{t}$ hitung $\geq \mathrm{t}$ tabel maka Ho ditolak dan $\mathrm{Ha}$ diterima artinya terdapat pengaruh yang signifikan antara perputaran kas, perputaran persediaan dan perputaran piutang terhadap return on assets (ROA) secara parsial.

2. Jika $\mathrm{t}$ hitung $<\mathrm{t}$ tabel maka Ho diterima dan $\mathrm{Ha}$ ditolak dan artinya tidak terdapat pengaruh yang signifikan antara perputaran kas, perputaran persediaan dan perputaran piutang terhadap return on assets (ROA) secara parsial.

\section{Uji Statistik F (Simultan)}

Untuk menguji pengaruh antara simultan antara variabel independen terhadap variabel dependen dikemukakan Sugiyono (2006 :144) dapat dirumuskan sebagai berikut :

$$
F=\frac{\frac{R^{2}}{K}}{\frac{\left(1-R^{2}\right)}{n-k}}
$$

Keterangan : $\mathrm{R}=$ Nilai koefesien korelasi ganda; $\mathrm{K}=$ Jumlah variabel; $\mathrm{n}$ = jumlah sampel; $\mathrm{f}=$ nilai $\mathrm{f}$ yang dihitung dengan tingkat signifikan $\alpha$ $=5 \%$

signifikansi :

$$
\text { Kriteria pengujian }
$$

1. Jika $F$ hitung $\geq F$ tabel maka Ho ditolak dan $\mathrm{Ha}$ diterima artinya terdapat pengaruh yang signifikan antara perputaran kas, perputaran persediaan dan perputaran piutang terhadap Return On Assets (ROA) secara simultan.

2. Jika $\mathrm{F}$ hitung $<\mathrm{F}$ tabel maka Ho diterima dan Ha ditolak artinya tidak terdapat pengaruh yang signifikan antara perputaran kas, perputaran persediaan dan perputaran piutang terhadap Return On Assets (ROA) secara simultan.

\section{HASIL}

\section{Perputaran Kas}

Berikut ini adalah tabel yang menunjukkan perputaran kas pada PT. Indofood Sukses Makmur, Tbk secara umum dapat ditampilkan seperti pada Tabel 3 berikut : 
Tabel 3

Data Penjualan Bersih, Rata-rata Kas dan Perputaran Kas PT. Indofood Sukses Makmur Tbk

Tahun 2008-2015

\begin{tabular}{|c|r|r|r|}
\hline \multirow{2}{*}{ tahun } & $\begin{array}{c}|c| \\
\text { Penjualan bersih (dalam } \\
\text { jutaan rupiah) }\end{array}$ & $\begin{array}{c}\text { Rata-rata kas } \\
\text { (dalam jutaan rupiah) }\end{array}$ & $\begin{array}{c}\text { Perputaran kas } \\
\text { (kali) }\end{array}$ \\
\hline 2008 & 38.799 .279 & 4.404 .629 & 9 \\
\hline 2009 & 37.140 .830 & 4.373 .019 & 8 \\
\hline 2010 & 38.403 .360 & 7.457 .091 & 5 \\
\hline 2011 & 45.332 .256 & 11.744 .200 & 4 \\
\hline 2012 & 50.059 .427 & 13.196 .038 & 4 \\
\hline 2013 & 57.731 .998 & 27.009 .222 & 2 \\
\hline 2014 & 63.594 .452 & 13.911 .906 & 5 \\
\hline 2015 & 64.061 .947 & 13.616 .847 & 5 \\
\hline
\end{tabular}

Sumber : Data diolah

Berdasarkan Tabel 5.1 diatas bahwa hasil perhitungan perputaran kas PT. Indofood Sukses Makmur, Tbk periode 2008-2015 mengalami peningkatan dan penurunan. Tahun 2008 jumlah perputaran kas adalah 9 kali dalam satu periode, tahun 2009 jumlah perputaran kas turun menjadi 8 kali dalam satu periode, pada tahun 2010 jumlah perputaran kas turun menjadi 5 kali dalam satu periode, pada tahun 2011 perputaran kas kembali turun menjadi 4 kali dalam satu periode, tahun 2012 jumlah perputaran kas adalah 4 kali dalam satu periode, pada tahun 2013 jumlah perputaran kas kembali turun menjadi 2 kali dalam satu periode, tahun 2014 jumlah perputaran kas naik menjadi 5 kali dalam satu periode, dan pada tahun 2015 jumlah perputaran kas adalah 5 kali dalam satu periode.

\section{Perputaran Persediaan}

Berikut ini adalah tabel yang menunjukkan perputaran persediaan pada PT. Indofood Sukses Makmur, Tbk secara umum dapat ditampilkan seperti pada Tabel 4 berikut:

Tabel 4

Data Harga Pokok Penjualan, Rata-rata Persediaan dan Perputaran Persediaan PT. Indofood Sukses Makmur Tbk Tahun 2008-2015

\begin{tabular}{|c|c|c|c|}
\hline \multirow{2}{*}{ Tahun } & \multicolumn{3}{|c|}{ Uraian } \\
\cline { 2 - 4 } & $\begin{array}{c}\text { Harga pokok } \\
\text { penjualan } \\
\text { (dalam jutaan } \\
\text { rupiah) }\end{array}$ & $\begin{array}{c}\text { Rata-rata } \\
\text { persediaan } \\
\text { (dalam jutaan } \\
\text { rupiah) }\end{array}$ & $\begin{array}{c}\text { Perputaran } \\
\text { persediaan } \\
\text { (kali) }\end{array}$ \\
\hline 2008 & 29.822 .362 & 5.116 .803 & 6 \\
\hline 2009 & 27.018 .884 & 5.589 .351 & 5 \\
\hline 2010 & 25.932 .908 & 5.380 .812 & 5 \\
\hline 2011 & 32.749 .190 & 6.090 .242 & 5 \\
\hline 2012 & 36.493 .332 & 7.159 .468 & 6 \\
\hline 2013 & 43.402 .144 & 7.971 .566 & 5 \\
\hline 2014 & 46.544 .646 & 8.307 .692 & \\
\hline
\end{tabular}




\begin{tabular}{|c|r|r|r|}
\hline 2015 & 46.803 .889 & 8.041 .102 & 6 \\
\hline
\end{tabular}

Berdasarkan Tabel 4 diatas bahwa hasil perhitungan perputaran persediaan PT. Indofood Sukses Makmur, Tbk periode 2008-2015 mengalami penurunan pada awal periode penelitian. Pada tahun 2008 jumlah perputaran persediaan adalah 6 kali dalam satu periode, tahun 2009 jumlah perputaran persediaan turun menjadi 5 kali dalam satu periode, tahun 2010 jumlah perputaran persediaan adalah 5 kali dalam satu periode, tahun 2011 perputaran persediaan adalah 5 kali dalam satu periode, tahun 2012 jumlah perputaran persediaan adalah 5 kali dalam satu periode, tahun 2013 jumlah perputaran persediaan adalah 5 kali dalam satu periode, tahun 2014 jumlah perputaran persediaan naik menjadi 6 kali dalam satu periode dan pada tahun 2015 jumlah perputaran persediaan adalah 6 kali dalam satu periode.

\section{Perputaran Piutang}

Berikut ini adalah tabel yang menunjukkan perputaran kas pada PT. Indofood Sukses Makmur, Tbk secara umum dapat ditampilkan seperti pada Tabel 5 berikut :

\section{Tabel 5}

Data Penjualan, Rata-rata Piutang dan Perputaran Piutang PT. Indofood Sukses Makmur Tbk

Tahun 2008-2015

\begin{tabular}{|c|c|c|c|}
\hline \multirow{2}{*}{ Tahun } & \multicolumn{3}{|c|}{ Uraian } \\
\cline { 2 - 4 } & $\begin{array}{c}\text { Penjualan } \\
\text { (dalam jutaan } \\
\text { rupiah) }\end{array}$ & $\begin{array}{c}\text { Rata-rata } \\
\text { Piutang } \\
\text { (dalam jutaan } \\
\text { rupiah) }\end{array}$ & $\begin{array}{c}\text { Perputaran } \\
\text { piutang (kali) }\end{array}$ \\
\hline 2008 & 38.799 .279 & 3.065 .743 & 12 \\
\hline 2009 & 37.140 .830 & 1.965 .432 & 19 \\
\hline 2010 & 38.403 .360 & 2.044 .746 & 19 \\
\hline 2011 & 45.332 .256 & 2.415 .030 & 19 \\
\hline 2012 & 50.059 .427 & 2.637 .677 & 17 \\
\hline 2013 & 57.731 .998 & 3.372 .285 & 14 \\
\hline 2014 & 63.594 .452 & 3.520 .014 & 19 \\
\hline 2015 & 46.803 .889 & 3.254 .641 & \\
\hline
\end{tabular}

Sumber : Data diolah

Berdasarkan Tabel 5 diatas bahwa hasil perhitungan perputaran piutang PT. Indofood Sukses Makmur, Tbk periode 2088-2015 mengalami peningkatan dan penurunan. Pada tahun 2008 jumlah perputaran piutang adalah 12 kali dalam satu periode, tahun 2009 jumlah perputaran piutang naik menjadi 19 kali dalam satu periode, tahun 2010 jumlah perputaran piutang adalah 19 kali dalam satu periode, tahun 2011 jumlah perputaran piutang adalah 19 kali dalam satu periode, tahun 2012 jumlah perputaran piutang adalah 19 kali dalam satu periode, tahun 2013 jumlah perputaran piutang turun menjadi 17 kali dalam satu periode, tahun 2014 jumlah perputaran 
piutang naik menjadi 18 kali dalam satu periode, dan pada tahun 2015 jumlah perputaran piutang kembali turun menjadi 14kali dalam satu periode.

\section{Return On Assets (ROA)}

Berikut ini adalah Tabel 6 yang menunjukkan Return On Assets (ROA) pada PT. Indofood Sukses Makmur, Tbk secara umum dapat ditampilkan pada tabel 5.4 berikut :

Tabel 6

Data Perhitungan ROA PT. Indofood Sukses Makmur, Tbk tahun 20082015

\begin{tabular}{|c|c|c|c|}
\hline \multirow{2}{*}{ tahun } & \multicolumn{3}{|c|}{ Uraian } \\
\cline { 2 - 4 } & $\begin{array}{c}\text { Laba bersih (dalam } \\
\text { jutaan rupiah) }\end{array}$ & $\begin{array}{c}\text { Total aktiva (dalam } \\
\text { jutaan rupiah) }\end{array}$ & $\begin{array}{c}\text { ROA } \\
(\boldsymbol{\%})\end{array}$ \\
\hline 2008 & 1.034 .389 & 39.594 .264 & 2,61 \\
\hline 2009 & 2.075 .861 & 40.382 .953 & 5,14 \\
\hline 2010 & 2.952 .858 & 47.275 .955 & 6,25 \\
\hline 2011 & 5.017 .425 & 53.585 .933 & 9,36 \\
\hline 2012 & 4.871 .745 & 59.324 .207 & 8,21 \\
\hline 2013 & 5.161 .247 & 78.092 .789 & 6,60 \\
\hline 2014 & 4.812 .618 & 85.938 .885 & 5,60 \\
\hline 2015 & 4.867 .347 & 91.831 .526 & 5,30 \\
\hline
\end{tabular}

Sumber : Data diolah

$\begin{array}{ll}\text { Berdasarkan Tabel } 6 & \text { diatas } \\ \text { dari hasil perhitungan } & \text { ROA }\end{array}$ mengalami kenaikan dan penurunan setiap tahunya, kemampuan perusahaan dalam menghasilkan laba dari aktiva. Pada tahun 2008 nilai ROA adalah 2,61\%, tahun 2009 nilai ROA naik menjadi $5,14 \%$, tahun 2010 nilai ROA naik menjadi 6,25\%, tahun 2011 nilai ROA naik menjadi $9,36 \%$, namun tahun 2012 nilai ROA turun menjadi $8,21 \%$, tahun 2013 nilai ROA turun lagi menjadi $6,60 \%$, tahun 2014 nilai ROA kembali turun menjadi $5,60 \%$ dan pada tahun 2015 nilai ROA adalah $5,30 \%$.

\section{Analisis Regresi Berganda}

Untuk mengetahui persamaan analisis regresi linear berganda pengaruh perputaran kas, perputaran persediaan dan perputaran piutang terhadap Return On Assets (ROA) berdasarkan output SPSS versi 20, maka dapat dilihat pada Tabel 6 dibawah ini :

Tabel 6

Coefficients $^{\mathbf{a}}$

\begin{tabular}{|c|c|c|c|c|c|c|}
\hline \multirow{2}{*}{\multicolumn{2}{|c|}{ Model }} & \multicolumn{2}{|c|}{$\begin{array}{l}\text { Unstandardized } \\
\text { Coefficients }\end{array}$} & \multirow{2}{*}{$\begin{array}{l}\text { Standardized } \\
\text { Coefficients } \\
\text { Beta }\end{array}$} & \multirow[t]{2}{*}{$\mathrm{t}$} & \multirow[t]{2}{*}{ Sig. } \\
\hline & & $\mathrm{B}$ & Std. Error & & & \\
\hline 1 & $\begin{array}{l}\text { (Constant) } \\
\text { log_per.kas } \\
\text { log_per.persediaan } \\
\text { log_per.piutang }\end{array}$ & $\begin{array}{r}-2,104 \\
-, 334 \\
, 834 \\
2,019\end{array}$ & $\begin{array}{r}2,640 \\
, 216 \\
1,917 \\
1,014\end{array}$ & $\begin{array}{r}-, 397 \\
, 165 \\
, 799\end{array}$ & $\begin{array}{r}-, 797 \\
-1,547 \\
, 435 \\
1,991\end{array}$ & $\begin{array}{l}, 470 \\
, 197 \\
, 686 \\
, 117\end{array}$ \\
\hline
\end{tabular}

Sumber: data olahan 
Berdasarkan pada Tabel 6 diatas, terlihat bahwa nilai konstanta (a) sebesar -2,104 dan koefesien regresi $\mathrm{X}_{1}-334, \mathrm{X}_{2} 0,834$ dan $\mathrm{X}_{3}$ 2,019. Nilai konstanta dan koefisien regresi (a, $\left.\mathrm{X}_{1}, \mathrm{X}_{2}, \mathrm{X}_{3}\right)$ ini dimasukkan dalam persamaan regresi linear berganda berikut ini :

$\mathrm{Y}=-2,104-0,334 \mathrm{X}_{1}+0,834 \mathrm{X}_{2}+$ $0,219 \mathrm{X}_{3}$

Persamaan diatas memiliki makna :

1. Nilai konstanta (a) bernilai negatif sebesar 2,104, artinya jika perputaran kas, perputaran persediaan dan perputaran piutang bernilai 0, maka Return On Assets (ROA) akan berkurang sebesar $2,104 \%$.

2. Nilai koefesien regresi variabel perputaran kas $\left(\mathrm{X}_{1}\right)$ adalah bernilai negatif sebesar 0,334 , artinya setiap kenaikan $1 \%$ perputaran kas akan menurunkan Return On Assets (ROA) sebesar $0,334 \%$ dengan asumsi variabel lain bernilai tetap. Karena menurut M. Tejo (2013) didalam penelitian terdahulunya jika perputaran kas bernilai negatif maka akan menurunkan nilai Return On Assets (ROA) dengan asumsi variabel lain bernilai tetap.

3. Nilai koefesien regresi variabel perputaran persediaan $\left(\mathrm{X}_{3}\right)$ adalah bernilai positif sebesar 0,834 , artinya setiap perputaran persediaan bertambah $1 \%$, maka Return On Assets (ROA) memiliki kecendrungan untuk bertambah sebesar $0,834 \%$ dengan asumsi variabel lain bernilai tetap.

4. Nilai koefesien regresi variabel perputaran piutang $\left(\mathrm{X}_{3}\right)$ adalah bernilai positif 2,019, artinya setiap perputaran piutang bertambah $1 \%$ maka Return On Assets (ROA) memiliki kecendrungan untuk bertambah sebesar 2,019\% dengan asumsi variabel lain tetap.

Pengaruh Perputaran Kas

Perputaran Persediaan dan

Perputaran Piutang Terhadap Return On Assets (ROA) Pada PT. Indofood Sukses Makmur Tbk periode 2008-2015.

\section{Hasil Uji t (Parsial)}

Tabel 6 diatas dapat diketahui hasil uji $t$ untuk masing-masing variabel independent $\left(\mathrm{X}_{1}, \mathrm{X}_{2}, \mathrm{X}_{3}\right)$ terhadap variabel dependent (Y), diman hasilnya adalah sebagai berikut :

1. Hasil pengujian parsial (uji t) untuk variabel $\mathrm{X}_{1}$ perputaran kas diketahui nilai $\mathrm{t}$ hitung $<\mathrm{t}$ tabel ($1,547<2,776)$ dan signifikansi > $0,05(0,197>0,05)$ maka Ho diterima dan Ha ditolak, artinya secara parsial terdapat pengaruh tetapi tidak signifikan antara perputaran kas terhadap Return On Asset (ROA).

2. Hasil pengujian parsial (uji t) untuk variabel $X_{2}$ perputaran persediaan diketahui nilai t hitung $<\mathrm{t}$ tabel $(0,435<2,776)$ dan signifikansi > 0,05 $(0,686>0,05)$ maka Ho diterima dan Ha ditolak, artinya secara parsial terdapat pengaruh tetapi tidak signifikan antara perputaran persediaan terhadap Return On Asset (ROA).

3. Hasil pengujian parsial (uji t) untuk variabel $\mathrm{X}_{3}$ perputaran piutang diketahui nilai t hitung < $\mathrm{t}$ tabel $(1,991<2,776)$ dan signifikansi > 0,05 $(0,117>0,05)$ maka Ho diterima dan Ha ditolak, artinya secara parsial terdapat pengaruh tetapi tidak signifikan antara perputaran piutang terhadap Return On Asset (ROA).

Berdasarkan hasil analisis data yang telah dilakukan diatas, 
menunjukkan bahwa variabel independent perputaran kas memiliki nilai signifikan $0,197>0,05$ hal ini terbukti perputaran kas tidak memiliki pengaruh yang signifikan secara parsial terhadap Return On Assets (ROA) pada PT. Indofood Sukses Makmur Tbk periode 20082015. Hasil penelitian ini menunjukkan bahwa pihak manajemen keuangan perusahaan Indofood Sukses Makmur, Tbk kurang efektif dalam mengelola kas yang dimiliki, sehingga perputaran kas yang terjadi dari tahun ke tahun rata-rata cendrung menunjukkan angka perputaran yang fluktuatif (naik turun). Dimana secara teori yang dikemukakan oleh Riyanto (2012:95) semakin tinggi perputaran kas ini akan semakin baik, berarti semakin tinggi efisiensi penggunaan kasnya dan keuntungan yang diperoleh akan semakin besar. Hasil penelitian ini sejalan dengan penelitian yang dilakukan Oktari Budiansyah (2012) yang menunjukkan bahwa perputaran kas tidak berpengaruh signifikan terhadap ROA.

Berdasarkan hasil pengujian pada penelitian ini bahwa perputaran persediaan tidak memiliki pengaruh yang signifikan secara parsial terhadap ROA. Perputaran persediaan memiliki nilai signifikan $0,686>0,05$ maka dapat dikatakan bahwa perputaran persediaan tidak berpengaruh terhadap ROA PT. Indofood Sukses Makmur, Tbk periode 2008-2015. Secara teori menurut Raharjaputra (2009:15) menyatakan bahwa semakin tinggi tingkat perputaran persediaan, kemungkinan semakin besar tingkat perusahaan akan memperoleh keuntungan begitu pula sebaliknya jika tingkat perputaran persediaannya rendah maka kemungkinan semakin kecil perusahaan akan memperoleh keuntungan (ROA). Hal ini tidak sejalan dengan penelitian yang dilakukan Budiansyah (2012), Tejo (2013) dan Deni (2014), yang menunjukkan bahwa perputaran persediaan memiliki pengaruh yang signifikan terhadap ROA.

Berdasarkan hasil pengujian pada penelitian ini bahwa perputaran piutang tidak memiliki pengaruh yang signifikan terhadap Return On Assets (ROA). Perputaran piutang memiliki nilai signifikan $0,117>$ 0,05 , Perputaran piutang yang tinggi dapat meningkatkan profitabilitas karena jumlah piutang tak tertagih semakin sedikit. Namun perputaran piutang yang terlalu tinggi juga dapat menurunkan profitabilitas. Hasil penelitian ini sesuai dengan teori yang dilakukan Supriyono (2009:11) penurunan perputaran piutang disebabkan karena lamanya penagihan piutang sehingga semakin lama pula piutang tersebut diubah menjadi kas, akibatnya perusahaan untuk meningkatkan laba berkurang dan akhirnya Return On Assets (ROA) dapat menurun. Hasil penelitian ini juga sesuai dengan penelitian sebelumnya yang dilakukan Budiansyah (2012) menunjukan bahwa perputaran piutang tidak berpengaruh signifikan terhadap profitabilitas perusahaan. Tetapi berbeda dengan hasil yang diteliti oleh Tejo (2013) dan Deni (2014) menyatakan bahwa perputaran piutang berpengaruh signifikan terhadap profitabilitas perusahaan.

\section{Hasil Uji F (Simultan)}

Untuk menguji ada atau tidaknya pengaruh perputaran kas, perputaran persediaan dan perputaran piutang terhadap Return On Assets (ROA) pada PT. Indofood 
Sukses Makmur, Tbk periode 20082015 secara simultan dengan menggunakan uji $\mathrm{F}$ dapat dilihat dari tabel dibawah ini :

\section{Tabel 7}

ANOVA $^{\mathrm{a}}$

\begin{tabular}{|l|l|r|r|r|r|r|}
\hline \multicolumn{2}{|c|}{ Model } & Sum of Squares & Df & Mean Square & F & Sig. \\
\hline 1 & Regression &, 165 & 3 &, 055 & 7,315 &, $042^{\mathrm{b}}$ \\
& Residual &, 030 & 4 &, 008 & & \\
& Total &, 195 & 7 & & & \\
\hline
\end{tabular}

Sumber: data diolah

Hasil analisis regresi dapat diketahui $\mathrm{F}$ hitung $>\mathrm{F}$ tabel $(7,315>$ $6,59)$ dan signifikan $<0,05(0,042<$ $0,05)$ maka Ho ditolak dan $\mathrm{Ha}$ diterima artinya terdapat pengaruh tetapi yang signifikan antara perputaran kas, perputaran

\section{SIMPULAN}

Berdasarkan hasil penelitian, maka kesimpulan dalam penelitian adalah :

1. Pengaruh perputaran kas,
perputaran persediaan dan perputaran piutang terhadap Return On Assets (ROA) pada PT. Indofood Sukses Makmur, Tbk periode 2008-2015 dapat dilihat secara :

a. Parsial

1) Tidak terdapat pengaruh yang signifikan antara perputaran kas terhadap Return On Assets (ROA) pada PT. Indofood Sukses Makmur Tbk periode 20082015, hal ini dibuktikan dengan nilai $\mathrm{t}$ hitung $<\mathrm{t}$ tabel $(-1,547<2,446)$ dan signifikansi > 0,05 $(0,197>$ $0,05)$ maka Ho diterima dan Ha ditolak.

2) Tidak terdapat pengaruh yang signifikan antara perputaran persediaan terhadap Return On Assets (ROA) pada PT. Indofood Sukses Makmur Tbk periode 2008-2015, hal ini dibuktikan dengan nilai $\mathrm{t}$ hitung < $\mathrm{t}$ tabel $(0,435<$ 2,446) dan signifikansi > $0,05(0,686>0,05)$ maka Ho diterima dan Ha ditolak.

3) Tidak terdapat pengaruh yang signifikan antara perputaran piutang terhadap Return On Assets (ROA) pada PT. Indofood Sukses Makmur Tbk periode 20082015, hal ini dibuktikan dengan nilai hitung $<\mathrm{t}$ tabel $(1,991<2,446)$ dan signifikansi > 0,05 $(0,117>$ $0,05)$ maka Ho diterima dan Ha ditolak.

b. Simultan

Terdapat pengaruh yang signifikan antara perputaran kas, perputaran persediaan dan perputaran piutang terhadap Return On Assets (ROA) pada PT. Indofood Sukses Makmur Tbk periode 2008-2015, hal ini dibuktikan dengan nilai $\mathrm{F}$ hitung > F tabel $(7,315>$ $6,59)$ dan signifikan $>0,05$ $(0,042>0,05)$ maka Ho ditolak dan $\mathrm{Ha}$ diterima artinya terdapat pengaruh yang signifikan antara perputaran kas, perputaran persediaan dan perputaran piutang secara bersamasama (simultan) terhadap Return On Assets (ROA). 
2. Besarnya pengaruh perputaran kas, perputaran persediaan dan perputaran piutang terhadap Return On Assets (ROA) pada PT. Indofood Sukses Makmur Tbk periode 2008-2015 dapat dilihat secara :

a. Parsial

1) Besarnya pengaruh kas terhadap Return On Assets (ROA) yaitu sebesar 0,464 atau 46,4\%. Hal ini menunjukkan bahwa secara parsial variasi perputaran kas hanya dapat menjelaskan variasi (pola pergerakan) nilai Return On Assets (ROA) hanya sebesar $46,4 \%$, sedangkan sisanya sebesar $53,6 \%$ dijelaskan oleh variabel-variabel lain.

2) Besarnya pengaruh persediaan terhadap Return On Assets (ROA) yaitu sebesar 0,174 atau 17,4\%. Hal ini menunjukkan bahwa secara parsial variasi perputaran persediaan hanya dapat menjelaskan variasi (pola pergerakan) nilai Return On Assets (ROA) sebesar $17,4 \%$ sedangkan sisanya sebesar $82,6 \%$ dijelaskan oleh variabelvariabel lain.

3) Besarnya pengaruh persediaan terhadap Return On Assets (ROA) yaitu sebesar 0,650 atau sebesar $65 \%$. Hal ini menunjukkan bahwa secara parsial variasi perputaran piutang hanya dapat menjelaskan variasi (pola pergerakan) nilai Return On Assets (ROA) hanya sebesar 65\%, sedangkan sisanya sebesar $35 \%$ dijelaskan oleh variabel-variabel lain. b. Simultan

Besarnya pengaruh perputaran kas, perputaran persediaan dan perputaran piutang terhadap Return On Assets (ROA) pada PT. Indofood Sukses Makmur Tbk periode 2008-2015 yaitu sebesar 0,846 . Dengan kata lain hal ini menunjukkan bahwa secara simultan besar persentase variasi ROA yang bisa dijelaskan oleh variasi dari variabel bebas yaitu perputaran kas $\left(\mathrm{X}_{1}\right)$, Perputaran persediaan $\left(\mathrm{X}_{2}\right)$ dan perputaran piutang $\left(\mathrm{X}_{3}\right)$ sebesar $84,6 \%$, sedangkan sisanya sebesar $15,4 \%$ dijelaskan oleh variabelvariabel lain diluar variabel penelitian.

\section{DAFTAR PUSTAKA}

Abdullah, M. Faisal, 2005. Dasardasar Manajemen Keuangan, Edisi Kedua, Cetakan Kelima, Penerbitan Universitas Muhammadiyah, Malang.

Agus Sartono. 2010. Manajemen Keuangan Teori dan Aplikasi, Edisi Keempat. Yogyakarta: BPFE.

Arbi, Rahma Syarif, 2013, Lembaga Perbankan Keuangan

Pembiayaan, Yogyakarta : BPFE.

Bambang Riyanto, 2001. DasarDasar Pembelanjaan Perusahaan, Edisi Keempat, Cetakan Ketujuh, BPFE Yogyakarta, Yogyakarta.

Bambang Riyanto, 2002, Dasardasar Pembelanjaan Perusahaan, Edisi Keempat, Yogyakarta : BPFE. 
Bambang Riyanto, 2011, Dasardasar Pembelanjaan Perusahaan, Edisi keempat, Penerbit : BPFE, Yogyakarta.

Bambang Riyanto, 2012, Dasardasar Pembelanjaan Prusahaan, Edisi 4, Yogyakarta : BPFE.

Brigham, Eugene F. And Joel F. Houston, 2001. Fundamentals Of Finnancial. Manajement Ninth Edition, Jakarta : Salemba Empat.

Brigham dan Houston, 2010, Dasardasar Manajemen Keuangan Buku I. (Edisi II). Jakarta : Salemba.

Dahlan Siamat, 2004. Manajemen Lembaga Keuangan, Edisi Keempat, Lembaga Penerbit Fakultas Ekonomi Universitas Indonesia.

Fahmi, Irham, 2011, Analisis Laporan Keuangan (Edisi 1), Bandung : alfabeta. Ghozali, Imam.

Farid dan Siswanto,2011, Analisis Laporan Keuangan, Jakarta : Bumi Aksara

H. Kusnadi, 2000, Akutansi Keuangan Menengah. Malang : Unibraw

Hadori Yunus, 2005, Akutansi Keuangan Lanjutan, Penerbit : Satya Wacana.

Harahap, Sofyan Syafri, 2008, Analisis Kritis atas Laporan Keuangan, Raja Grafindo Persada, Jakarta.

Harahap, Sofyan Syafri, 2009, Analisis Kritis atas Laporan Keuangan, Raja Grafindo Persada, Jakarta.

Handoko T. Hani, 2000, Manajemen Personalia dan Sumber Daya Manusia, Edisi II, Cetakan Keempat Belas, Penerbit BPFE, Yogyakarta.
Hasibuan, 2000, Manjemen Sumber Daya Manusia. Bumi Aksara, Jakarta Imam, Ghozali.

Hendra S. Raharja Putra, 2009, Manajemen Keuangan dan Akutansi, Jakarta : Salemba Empat.

Horngren, et.al, 2003, Akutansi Di Indonesia, Buku Satu dan Dua, Jakarta: Salemba Empat, Simon \& Schuster (Asia) Pte.Ltd.Prentice-Hall.

Ikatan Akutansi Indonesia, 1994, Standar Akutansi Keuangan, Jakarta : Salemba Empat.

I Made Sudana, 2011, Manajemen Keuangan Perusahaan, Erlangga, Jakarta.

Indriyo Gitosudarmo dan Basri, 2002, Manajemen Keuangan, Edisi 3, BPFE. Yogyakarta.

Irman Deni, 2014, Perputaran Kas Perputaran Persediaan dan Perputaran Piutang terhadap Profitabilitas pada Perusahaan Manufaktur yang terdaftar di BEI.

Irawati, Susan, 2006, Manajemen Keuangan, Cetakan Kesatu, Bandung: PT. Pustaka.

Ismiyanti dan Hanafi, Mahmud M, 2010, Manajemen Keuangan, Cetakan Kelima, Yogyakarta : BPFE

Kasmir, 2008. Analisis Laporan Keuangan, Raja Grafindo Persada, Jakarta.

Kasmir, 2011, Analisis Laporan Keuangan, Jakarta : PT. Raja Grafindo.

Kasmir, 2013, Analisis Laporan Keuangan, Edisi I, Cetakan ke-6, Jakarta: Rajawali Pers.

Kosasih dan Soewedo, 2009, Manajemen Perusahaan Pelayanan, Jakarta: PT. Raja Grafindo Persada. 
L. Daf, 2002, Manajemen Edisi Kelima Jilid Satu, Jakarta : Erlangga.

Lukman Syamsudin, 2001, Manajemen Keuangan

Perusahaan, Jakarta : Bina Graha.

Lukman Syamsudin, 2002, Manajemen Keusngan Perusahaan, Jakarta: PT Raja Grafindo Persda.

Lyn M. Fraser dan Aillen Ormiston, 2008, Memahami Laporan Keuangan, Edisi Ketujuh, Indeks, Jakarta (Terjemahan).

Mamduh M. Hanafi dan Abdul Halim, 2005, Analisis Laporan Keuangan, Penerbit : UPP STIM YKPN, Yogyakarta.

Mohammad Tejo Suminar, 2013, Pengaruh Perputaran Kas Perputaran Persediaan dan Perputaran Piutang terhadap Profitabilitas pada Perusahaan Sektor Industri Barang dan Konsumsi Tahun 2008-2013.

Mardiyanto, Handono, 2009, Intisari Manajemen Keuangan, Jakarta : Grafindo.

Martono dan D. Agus Harjito, 2004, Manajemen Keuangan, Penerbit Ekonisia. PT. Raja Grafindo Persada, Jakarta.

Martono dan D. Agus Harjito, 2005, Manajemen Keuangan, Penerbit Ekonisia. PT. Raja Grafindo Persada, Jakarta.

Munawir, 2002, Analisis Laporan Keuangan, Yogyakarta : Liberty.

Munawir, 2004. Analisa Laporan Keuangan. Edisi Keempat, Cetakan ke-13. Yogyakarta: Liberty.

Munawir, 2010, Analisis Laporan Keuangan, Edisi 4, Yogyakarta : Liberty
Oktari Budiansyah, 2014, Pengaruh Perputaran Kas Perputaran Persediaan dan Perputaran Piutang terhadap Profitabilitas Manufactur Basic Industry and Chemicals tahun 2012-2014.

R.A. Supriyono, 2009, Sistem Pengendalian Manajemen, (Edisi 1), Penerbit: BPFE.

S. Munawir, 2007, Analisa Laporan Keuangan, Liberty, Yogyakarta.

Suad Husnan, 2004, Dasar-Dasar Teori Portofolio dan Analisis Sekuritas, Edisi

Ketiga, Cetakan Pertama, UPP AMP YKPN, Yogyakarta

Suad Husnan, 2004, Dasar-Dasar Teori Portofolio dan Analisis Sekuritas, Edisi

Ketiga, Cetakan Pertama, UPP AMP YKPN, Yogyakarta.

Sumarsono. 2004. Akutansi Pengantar. Edisi Revisi. Jakarta : PT. Salemba Empat. Sutrisno, 2003, Manajemen Keuangan, Edisi Pertama, Cetakan kedua, Ekonisia, Yogyakarta.

Sutrisno, 2007, Manajemen Keuangan, Yogyakarta. : Ekonisia.

Sutrisno, Edi. 2009, Manajemen Sumber Daya Manusia Edisi Pertama, Jakarta : kencana Prenada Media Group.

Sutrisno, 2012, Manajemen Keuangan Teori Konsep dan Aplikasi (8 th ed), Yogyakarta : Ekonisia. Yuli Soesotio.

Van Horne, James C. dan John M. Wachowicz, Jr, 2005. Prinsip-prinsip Manajemen Keuangan, Buku Satu, Edisi Kedua Belas, Alih Bahasa oleh Dewi Fitriasari dan Deny Arnos Kwary, Salemba Empat, Jakarta . 